\title{
THE LAW RELATING TO DEPOSITS RECEIVED BY INSOLVENT BANKS.'
}

A bank is legally viewed in a double aspect, as a bailee and as a debtor. In receiving a special deposit that is to be returned, like a bond or certificate of stock, a bank is. a bailee, and governed by the law pertaining to that relation. In receiving money on general deposit, a bank is a debtor, consequently when it is lost, no matter what may be the cause, by improvident lending or theft, by fire or other physical destruction, the bank must respond, just like an ordinary borrower of money. Again, the depositor does not expect to receive the identical money deposited, but other money of equal value. ${ }^{2}$

Nevertheless, the law regards a general deposit as something more than a loan. If an individual should borrow from another and spend all the money in one hour in speculation or in betting at a horse-race, the lender would have no cause of action against the borrower. He has not a word to say concerning the borrower's use of his money, unless an agreement concerning its use was made before lending. But a bank, notwithstanding its relationship towards the creditor, can make no such free use of its bor-

ANazysis:

I. Relationship of bank to depositor.

2. A general deposit is something more than a loan.

3. Bank has authority to receive special and contingent deposits.

4. Deposits by trustees, executors, guardians, administrators, etc

5. A bank may select its depositors.

6. It has no right to receive deposit when insolvent.

7. Construction of prohibitory statutes.

8. Nature of act is not affected by irregular organization of bank

9. When can the deposit itself, or its substitute, be recovered.

a. There must have been an actual deposit.

b. Minst be traced.

c. If general fund exists of which it forms a part it can be recovered.

d. Effect of reducing and subsequently increasing this fund.

e. General deposit cannot be depleted to pay trust depositor.

f. A trust check must be returned if existing, or the amount if collected, after bank's failure.

'Marine Bank v. Fulton Bank, 2 Wall. 252; Matter of Patterson, 18 Hun. 221: Dounes v. Phanix Bank, 6 Hill, 297; Commercial Nat. Bonk v. Henninger, 105 $\mathrm{Pa}$.96; Kecne v. Collicr, I Met. (Ky.) 415. $43^{8}$ 
rowed money. It is a borrower with restrictions on its pcwer to lend; and these flow out of the conception that the bank, after all, is the keeper of the depositor's money, and this conception is strengthened by the fact that nothing is paid directly for the use of the loan.

While the authority of a bank to receive general deposits has always existed, its authority to receive special deposits has on some occasions been questioned, ${ }^{3}$ especially that of national banking associations." This was because the right was not enumerated among their specific powers, but the doubt was long ago settled in their favor.

In like manner a bank has a right to receive the deposit of a fund in controversy, to abide the event of litigation or an award, or to become payable on a contingency to some other person than the depositor. ${ }^{\circ}$

An administrator, executor, guardian, or other trustee may deposit funds in possession temporarily in a bank while awaiting investment or distribution, partly for the purpose of their safekeeping and partly to derive an income therefrom. $^{7}$ But he must exercise care in the selection of a depository. In a recent case the court declared that the trustee "will be held to that degree of care, at least, that prudent and cautious business men ordinarily exercise in their own affairs. But this duty is not discharged by depositing the funds in any bank. Nor would it be by depositing it without inquiry or investigation as to the standing of the depository. He must have reasonable grounds to believe, and in good faith believe, the irstitution to be solvent, before he deposits the estate's funds with it." 8

Foster y. Essex Bank, i7 Mass. 479

- First Nat. Bank v. Ocean Nat. Bank, 60 N. Y. 278; Wiley v. First Nat. Baitk, 47 Vt. 546; Whitucy v. First Nat. Bank, 50 Vt. 388; Mechler v. First Nat. Bank, 42 Md. 581 .

- First Nat. Bank v. Grahaim, ioo U. S. 699; Patterson v. Syracuse Nat. Bank, 80 N. Y. 82, containing a review of authorities; see also First Nat. Bank v. Zent, 39 Ohio Ch. 105.

Bushnell v. Chautauqua Co. Nat. Bark, 74 N. Y. 290; Ransas Nat. Bank v. Quinton, 57 Kan. 750; Brown \%. Kinsley Ex. Bank, $5 I$ Kan. 359; Amcrican Nat. Bank v. Presnall, $58 \mathrm{Kan} .69$. 6ra.

Germania Safcty Vault and Trust Co. v. Driskelr, 66 S. W. (Ky.)

Ibid. 
He must therefore exercise proper care in selecting the depository. He should not select one in another state.10 Having done this he is relieved, unless the institution at a later period becomes unsafe and he is negligent in not learning of its changed condition. A deposit made by judicial order furnishes complete protection. ${ }^{11}$

The deposit must be made in a way to indicate its true trust character. A guardian or other trustee who makes the deposit in his own name, whatever be his intention, is liable for the consequences. ${ }^{12}$ "No matter what he intends to do," says Justice Porter, " or what the cashier or clerk may think he is doing, the deposits must wear the impress of the trust. . . . He cannot so enter them as to call them his. own to-day if they are good, and to-morrow, if bad, ascribe them to the estate, or shift them in an emergency from one estate to another." 13 In some jurisdictions a less stringent rule has been applied, but it ought not to be favoregd. ${ }^{14}$ Furthermore, to permit the depositor to set aside the entry of his deposit by showing that really the deposit belonged to another, or vice versa, is a dangerous proceeding. ${ }^{15}$ Such evidence might be safely used to show that a mistake had been made in entering the deposit, but it ought not, we think, to be employed for any other purpose:

A bank is not required to keep the deposits only of those persons whom it wishes to serve, ${ }^{10}$ and may close an

- In re Post's Estate, Myrick, Prob. (Cal.) 230; In re Law's Estate, 144 Pa. 499; State v. Gooch, 97 N. C. 186.

${ }^{20}$ State v. Gooch, 97 N. C. 186 . The soundness of this position may be questioned; the state fence is no protection. On one occasion a guardian deposited his ward's money with a banking firm of which he was a member, but the impropriety of the act was not questioned. Ogburn v. Wilson, $93 \mathrm{~N}$. C. 115 and $96 \mathrm{~N}$. C 211.

in O'Hara v. Shepherd, 3 Md. Ch. 306. See State v. Gooch, 97 N. C. 186.

${ }^{12}$ Booth v. Wilkinson, 78 Wis. 652; Williams. v. Williams, 55 Wis. 300 , reviewing many decisions; Mason v. Whitthorme, 2 Cald. (Temn.) 242; Jenkins v. Waller, 8 Gill \& J. 218; Norris v. Hero, 22 La. Ann. 605: Robinson v. Ward, 2 Car. \& Payne, 59 Contro, Parsley v. Martin, 77 $V_{2} .376$.

MicAlister v. Commonzcealth, $30 \mathrm{~Pa}$. 536; Estate of Low, $144 \mathrm{~Pa}$. 499

${ }^{26}$ Parsley v. Martin, 77 Va. 376; Bcasley v. Watsox, $4 \mathrm{I}$ Al2 234

${ }^{2}$ Parsley v. Mfartin, 77 Va. 376; Bcasley v. Watson, 41 Ale 234

"Thatcher v. Bank, 5 Sand. (N. Y.) 121. 
account at any time by tendering the amount due to the depositor and declining to receive more. ${ }^{17}$ Some banks decline to open accounts with depositors who are in every way worthy because they do not expect to keep a deposit largo enough to be remunerative.

A bank has no right to receive a deposit when it is insolyent. By common law as well as statute the officers of banks are liable for receiving deposits when their institutions are in this condition. ${ }^{18}$ Of late, statutes of this nature have been generally enacted, which apply also to private banks and bankers. Such legislation is constitutional, nor is a statute declaring that the failure, suspension, or involuntary liquidation of a banker within a fixed period, thirty days, for example, prima facie evidence of his intent to defraud, unconstitutional in depriving him of the presumption of innocence. ${ }^{10}$

In construing these statutes the place where the deposit was received is not essential, ${ }^{20}$ nor the receiver. ${ }^{21}$ If the deposit were actually taken and received by the officers of the bank knowing that it was hopelessly insolvent, with the intention of returning it, ${ }^{22}$ the wrongful deed has been committed ; ${ }^{23}$ the deposit, if still existing, can be recovered, and the officers may be punished.24

${ }^{2}$ Chicago Marive and Fire Ins. Co. v. Stanford, $28 \mathrm{III.} 168$.

21 See note 26.

- State v. Beach, 147 Ind. 174; Robertson v. People, 20 Colo. 279; McClure v. People, 27 Colo. 358; Meadowcroft v. People, 163 III. 56; Brown v. People, 173 IIl. 34; State v. Buck, 120 Mo. 479; Baker v. State, 54 Wis. 368

In Alabama a statute providing that a banker who receives a deposit knowing that he is insolvent is guilty of 2 misdemeanor is declared to be a violation of the constitutional provision that no person shall be liable for a debt: Carr v. State, 106 Ala. 35.

State v. Yetzer, 97 lowa, 423; Carr v. State, ros Ala 4

* Carr v. State, 104 Ala. 4; State v. Yctser, gr Iowa, 423; State v. Eifert, 102 Iowa, 188; State v. Cadwell, 79 Iowa, 432; State $\nabla$. Sattley, I3I Mo. 464; Baker v. State, 54 Wis. 368

${ }_{2}$ Commonzuealth v. Junkin, $170 \mathrm{~Pa}_{2}$ 194, reversing $16 \mathrm{~Pa}$. Co. Ct. 116.

2 State 7. Beach, 147 Md. 74; American Trust and Savings Bank v. Gueder Mffg. Co., I50 III. 336; First Nat. Bank v. Strauss, 66 Miss. 479; Hyland v. Roe, III Wis. 361 ; Richardson v. Denegre, 356 C. A. 452; Richardson v. N. O. Debenture Redemption Co., 42 C C. A. 6ig; Richardson v. N. O. Coffee Co., 43 C. C A. 583.

"State v. Beach, 147 Md. 74; Meadoweroft v. People, 163 Ill. 56; Baker v. State, 54 Wis. 368. 
The two principal difficulties in executing these statutes are, first: whether the bank was insolvent within the meaning of the law at the time of receiving the deposit. The general rule may be thus stated: The officers of a bank who receive a check on deposit after it has become insolvent, knowing that failure is impending, violate the law and must answer for the consequences. ${ }^{25}$

In one of the many cases that might be mentioned the Supreme Court of the United States declared that when a bank has become hopelessly insolvent, and its president knows that it is so, it is a fraud to receive deposits of checks from an innocent depositor, ignorant of its condition, and he can reclaim them or their proceeds. ${ }^{20}$ In a more recent case the Circuit Court of Appeals said: "A banker who knows that he is hopelessly insolvent cannot honestiy continue business and receiye money from his customers. He may not intend to defraud a particular customer, but he will be held, of course, to have intended the inevitable consequences of his act-that is, to cheat and defraud all persons whose money he receives and whom he fails to pay before he stops business." ${ }^{27}$ And the offence is complete when the deposit was received, whether this was before or after a prescribed period of insolvency. The only effect of such a limitation is, if a bank fails within the period prescribed, thirty days or some other, after receiving the deposit, this is regarded as prima facie evidence of an intention to defraud, but the act-may be committed, though the deposit was received before. $^{28}$

- Cases under notes 21 and 23.

* St. Louis and San Francisco R. v. Johnston, I33 U. S. 566.

"Richardson v. New Orleans Coffee Co., 43 C. C. A. 583, 587; Lake Erie R. v. Indianapolis Nat. Bank, 65 Fed. 690 ; Peck v. First Nat. Bank, 43 Fed. 357; Wasson v. Hawkins, 59 Fed. 233; Am. Trust and Savings Bank v. Gueder Mfg. Co., 150 III. 336; Bank v. Gregg, 37 IIL App. 425; First Nat. Bank v. Strauss, 66 Miss. 479; Higgins v. Hayden, 53 Neb. 61; Perth Amboy Gaslight Co. v. Middlesex Co. Bank, 60 N. J. Eq. 84; Manufacturers Nat. Bank v. Continental Bank, I48 Mass. 553; Grant v. Walsh, 145 N. Y.; Cragic v. Hadley, 99 N. Y. 133; Metropolitan Nat. Bank v. Loyd, 90 N. Y. 530; Blair v. Hill, 50 N. Y. App. Div. 33 ; State v. Sattley, 131 Mo. $164 ;$ Williams v. Cox, 99 Tenn. 403; Bruner v. Bank, 97 Tenn. 540; McClure v. People, 27 Colo. 358

Lanterman v. Travous, 73 III. App. 670. Such a rule of evidence is not unconstitutional. Stafe v. Beach, 147 Ind. 74 . The Illinois statute 
The nature of the act is not affected by the irregular organization of one's bank. ${ }^{29}$ An officer cannot thus shield himself by his own wrong, or that of another officer who has omitted, either intentionally or otherwise, to comply with the law pertaining to the bank's organization. But an officer who should receive deposits while having his bank examined in good faith to find out whether or not it was insolvent would not be guilty of fraud in so doing. ${ }^{30}$ Nor should the knowledge of a managing officer of his bank's insolvency be imputed to other officers who are less active. To hold an officer he must be guilty of actual, and not simply constructive, fraud. ${ }^{31}$

Notwithstanding the insolvency of a bank at the time of receiving a deposit, and its deceptive and wrongful action, its subsequent recovery may not be easy. This is the other principal difficulty in executing the statutes pertaining to the subject. The law is in a transitory stage; many of the older decisions are no longer in harmony with the newer rules. To recover a deposit, on the ground that it ought not to have been received, there must have been an actual deposit as distinguished from the mere crediting of a check to the depositor. ${ }^{32}$ But when an actual deposit of money, checks, notes, or other property has been made, and is still in the bank, it can be recovered by replevin or other appropriate action. ${ }^{33}$ This rule is everywhere applied.

If the deposit has been received and can be traced, or has become mingled with an existing fund, it can be re-

also appiies to civil proceedings. Am. Trust and Savings Bank v. Gucder Mfg. Co., 150 III. 336.

$\rightarrow$ State v. Buck, 120 Mo. 479.

"Perth Amboy Gas.Light Co. v. Middlesex Co. Bank, 60 N. J. Eq. 84

"Quinn v. Earle, 95 Fed. 728; Perth Amboy Gas Light Co. v. Middlesex Co. Bank, 60 N. J. Eq. 84; Stapleton v. Odell, 21 N. Y. Mise 94. See McClure v. Pcople, 27 Colo. 358.

"Kansas State Bank v. First State Bank, 62 Kan. 788; Travellers Ins. Co. v. Caldwell, 59 Kan. 156; Middland Nat. Bank v. Brightwell, I48 Mo. 358; Perth Amboy Gas Light Co. v. Middlesex Co. Bank, 60 N. J. Eq. 84; Sherwood v. Milford State Bank, 94 Mich. 78; Quinn v. Earle, 95 Fed. 728, 731.

"Com. Ex. Nat. Bark v. Solicitors Loan and Trust Co., I88 Pa. 330; Furber v. Stcphens, 35 Fed. I7; Cragie v. Hadley, 99 N. Y. 13I; In re Commercial Bank; 1 Ohio N. P. 358. 
covered in an equitable action. ${ }^{34}$ Logically, therefore, a portion of the fund that exists or can be traced into another form can be recovered. ${ }^{35}$ This principle is everywhere applied.

As money usually has no earmark, and when taken by a bank is, except on rare occasions, mingled with the general mass, the modern rule in many courts, ${ }^{36}$ though not all, ${ }^{37}$ is if the general fund were increased by that amount, it can be recovered or any portion that still exists. This rule, doubtless, will everywhere prevail.

On the other hand, if the deposit has been paid out or mingled with a larger fund from which many payments have been made, and there is no clear evidence that the deposit or any portion still remains in the general fund, a similar amount cannot be recovered therefrom. To justify such a segregation there must be satisfactory proof that the deposit in controversy is still in the general fund. To trace a deposit into such a fund will not suffice. ${ }^{38}$

Of course, this general fund is constantly changing, and after the addition of a trust deposit the same as before. But when payments are made after receiving a trust deposit, the courts presume that the bank parts with its own money

* National Bank. v. Insurance Co., I04 U. S. 54; St. Louis Brewing Ass'n v. Austin, 100 Ala. 313; People v. City Bank, 96 N. Y. 32 ; Peale v. Ellicott, 30 Kan. 156; Harrison v. Smith, 83 Mo. 210; Grignon v. First Nat. Bank, 22 Mont. 140, 145.

Importers' and Traders Nat. Bank y. Peters, 123 N. Y. 272.

- Standard Oil Co. v. Hawkins, 20 C. C. A. 468; Metropolitan Nat. Bank v. Campbell Com. Co., 77 Fed. 705; Myers v. Board of Education, 5I Kan. 87; Bishop. v. Mahoney, 70 Minn. 238, 240; Cavin v. Gleason, 105 N. Y. 256; Importers' and Traders' Nat. Bank v. Peters, 123 N. Y. 272; First Nat. Bank v. Hummel, 14 Colo. 259; Windstanley v. Second Nat. Bank, 13 Ind. App. $544 ;$ Nurse v. Satterlee, 8r Iow2, 491, 495; Bradley v. Chesebrough, III Iowa, 126, 136; Carley v. Grazes, 85 Mich. 483; Sherwood v. Central Mich. Savings Bank, 103 Mich. Iog; see Board of Fire Com'rs y. Wilkinson, I19 Mich. 655; Middland Nat. Bank v. Brightwell, 148 Mo. 358.

"Philadelphia Nat. Bank y. Dou'd, 38 Fed. I72; Little v. Chadwick, I51 Mass. 109; Slater v. Oriental Mills, 18 R. I. 352

Bishop v. Malioney. 70 Minn. 238; In re Seven Corners Bank, 58 Minn. 5; Monotuck Silk Co. v. Flanders, 87 Wis. 237; Bradley v. Chesebrough, 111 Iowa, 126; Slater v. Oriental Mills, $18 \mathrm{R} 1.352$; Boord of Fire Com'rs v. Wilkinson, 119 Mich. 655; Richardson v. Louiszille Banking Co., 36 C. C. A. 307; see Guignon v. First Nat. Bank, 22 Mont. 140, 145. 
first, so that if the general fund has not been reduced below the amount of the trust fund, it still remains. ${ }^{30}$

Suppose the general fund is reduced by ordinary payments very considerably below the amount of the trust fund, yet at the time of the bank's failure contains an equivalent or even larger sum; as the trust fund to some extent has surely been paid out, the replenished fund has a different composition. On this question the courts again divide, some holding that the trust depositor can recover only the balance of the general fund when it was at the lowest point, ${ }^{40}$ assuming that this balance only was trust money; others. holding that the trust depositor can take all there was at the time of the bank's failure, ${ }^{41}$ if need be, to pay his deposit, because there is nothing wrong in law and morals in thus paying the trust deposit. Is there any flaw in this reasoning so long as the money used for restoring the trust fund is not taken from some other equally meritorious owner?

All will admit that a depositor who has been deluded in making a deposit when a bank was insolvent has a higher claim to recover than the depositor who put in his money when the bank was in a flourishing condition. All will agree that the wrongdoers should be punished, but it is quite another thing to take the money from one class of depositors to pay another class. The trust depositor has indeed a higher claim against the bank; but is it just to satisfy that claim by taking the amount in fact from another innocent depositor? ${ }^{42}$ As the Supreme Court of Iowa has well said: ${ }^{43}$ "That a person is a trust depositor does not of itself entitle him to preference over general creditors. To obtain that right, he must show by presumption of law or otherwise that his fund has been preserved in the hands of the assignee as an increase of the assets of the estate,

- Continental Nat. Bank v. Wicms, 69 Tex. 489; Inporters and Traders' Nat. Bank v. Peters, I23 N.'Y. 272; Bishop v. Mahoney, 70 Minn. 238; Nonotuck Silk Co. v. Flanders, 87 Wis. 237; Boord of Firc Com'rs v. Wilkinson, ing Mich. 655.

"See Bishop v. Mfaloucy. 7o Minn. 238, 240.

"Davenport Fiour Co. v. Lamp. 80 lowa, 722 ; see remarks on this case in Jones v. Chesebrough, 105 Iowa, 303, 305.

- Ifiddland Nat. Bank v. Brightuell, $148 \mathrm{Mo}$. $358,365$.

a Bradley v. Chicscbrough, ill Iowa, 126, 136. 
from which it may be taken without infringement of the rights of general creditors." In permitting a trust depositor to recover his money it must be his, and not the deposit of another. If his money has been paid out by the bank to other depositors on their checks, payable to themselves or to third parties, surely the bank in no sense is any longer the actual possessor; on the other hand, if it were paid to a borrower on a loan, who had not yet parted with it, the depositor's right thereto by that rule would exist.

Legal presumptions have often served as valuable rules in deciding cases, but injustice may be done by erroneous application of them. When the fact of a trust deposit is not questioned the rule is clearly settled that it can be recovered if it, or its substitute, can be traced into any other form, or has become or remains a part of an existing fund. But another rule must also be kept in sight-a fund belonging to another depositor, or to him in common with trust depositors, cannot be diverted to pay exclusively one class to the manifest loss of the other. Nor must the presumption we have been considering be employed to accomplish this purpose. It is an artificial presumption and should never stand in the way of an inquiry into the facts. If they fail to show what use was made of a trust deposit, the courts should be slow to permit a recovery based solely on this presumption. When a trust deposit has been mingled with another fund and is truly there, it may be reclaimed by the trust depositor, but when its existence rests on.a presumption that is probably opposed to fact, or at best on uncertainty respecting the retention or use of a trust deposit, a court may well hesitate to give precedence to the claims of a trust depositor on the slender basis of this presumption.

Three. classes of cases at least exist to which this presumption should be dissimilarly applied:

$\because$ (I) Those in which the bank has no knowledge that the deposit is a trust fund-for example, a deposit made by an agent against his principal's express or implied direction in his own name. Surely in such a case the bank would not reserve the deposit in making payments. Suppose five thousand dollars of trust money is mingled with a general 
fund of the same amount, and that.subsequently four thousand dollars is paid out? If the bank at the time of receiving the trust money or afterivards, previous to its payment, did not know that it was trust money, or did know and never returned it, is not the presumption much stronger than the other that it made this payment indiscriminately from the general fund without the slightest thought of the source whence it came? If so, would not a juster rule apportion this payment equally from the trust money and the other two thousand dollars from each, instead of taking it all from the original five thousand dollar fund, still leaving the trust money intact besides a thousand dollars more?

(2) In like manner a bank may receive a trust deposit knowing its true character, but, not regarding the law, mingles it with its general fund and pays it out without caring a whit about its legal obligations. Is not the application of the presumption in this class of cases without a reasonable basis?

(3) A third class of cases may be mentioned to which the presumption may be properly applied, or in which the fact may be shown, that the bank did seek to preserve the trust deposit. But when a bank receives a deposit knowing that it is in an insolvent condition, thus clearly violating the law, is it reasonable to presume that it will make the slightest distinction in the use of its deposits?

This presumption has been made to serve a twofold purpose- to preserve a fund for a trust depositor and to lessen the wrong-doing of the bank officers in the receipt and use of it. The facts in many a case in which this presumption has been applied have shown that the officers were utterly indifferent to the law in the general conduct of their bank; is it not quite illogical, therefore, to maintain that in this particular matter they sought to regard the law in the interest of the true owner of the deposit? The only case in which the presumption ought to be applied is the one in which the bank knew, either at the time of receiving the deposit or afterwards while it was in its possession, its true trust character, and in the keeping and use of it sought to observe the law. 
448 DEPOSITS RECEIVED BY INSOLVENT BANKS.

Do not these suggestions, dropped by the wayside of discussion, clearly show that this artificial presumption ought to be more carefully applied in the determination of the rights of parties in these difficult controversies?

Lastly, checks received just before a bank's failure, in violation of law, must be returned; and if they have been sent away for collection, the proceeds always belong to the depositor, though collected after the bank's failure. When, however, they have been rightly received before its failure and rightfully credited to the sender by reason of an agreement to treat them in this manner, then the proceeds can usually be kept by the collecting bank.

Albert S. Bolles.

"Levi v. National Bank, 5 Dill. 104; Commercial Nat. Bank 7. Armstrong, 148 L. S. 50; Blair v. Hill, 50 N. Y. App: 33; First Nat. Bank v. Strauss, 66 Miss. 479; Richardson v. Denegre, 35 C. C. A 452; Richardson v. N. O. Coffee Co., 43 C. C. A. 583 ; In re Hovens, 8 Ben. 309; Grignon v. First Nat. Bank, 22 Mont. 140. 